\title{
Chromosome 16p11.2 Deletion Syndrome
}

National Cancer Institute

\section{Source}

National Cancer Institute. Chromosome 16p11.2 Deletion Syndrome. NCI Thesaurus.

Code C120408.

A microdeletion at $16 p 11.2$, characterized by a predisposition to obesity, developmental delay and autism spectrum disorders. 